\title{
Statistical descriptions of delivered quantity of water by sources in the federation of Bosnia \& Herzegovina
}

\author{
Amna Aščić ${ }^{*}$, Mirsad Imamović ${ }^{2}$ \\ ${ }^{1}$ Institute for Statistics of Bosnia and Herzegovina, amnatravnik@gmail.com, Bosnia and Herzegovina \\ ${ }^{2}$ International University Travnik, mimo.mirsad@hotmail.com, Bosnia and Herzegovina
}

\begin{abstract}
Bosnia and Herzegovina is a country rich in unpolluted water resources which could in the future become the driving force of its economic development. In accordance with EU legislation, adopted in 2006, the Federal Law on Water, which among other things regulates the amount of water delivered in order for their sustainable use. The purpose of this study is to determine the trend and statistical descriptions of the amount of water delivered to the sources in the Federation of Bosnia \& Herzegovina (FB\&H), for the period 2001-2015. The minimum value of the total amount of water delivered in FB\&H for the period 2001-2015 (in thousands $\mathrm{m}^{3}$ ) was $216620 \times 10^{3}\left(\mathrm{~m}^{3}\right)$ of water in 2014 and the maximum $237480 \times 10^{3}\left(\mathrm{~m}^{3}\right)$ of water in 2005.
\end{abstract}

\section{Introduction}

$\mathrm{B}$ OSNIA and Herzegovina is a country in Southeastern Europe, located in the west part of the Balkan Peninsula. Border states of Bosnia and Herzegovina are the Republic of Serbia at north-east, Republic of Croatia at the north, west and south and Republic of Montenegro at south-east.

It is administratively divided in to entities and one district: Federation of Bosnia \& Herzegovina (FB\&H) and Republic of Srpska (RS) and Brčko District.

According to the census from 2013, the total number of people living in FB\&H is 3531159.

Total surface of FB\&H is $51209,2 \mathrm{~km}^{2}$, of which the land surface is $51197 \mathrm{~km}^{2}$ and the surface of coastal sea is $12,2 \mathrm{~km}^{2}$. Territory of FB\&H covers two river basins: basin of the river Sava that includes 75,7\% and the basin of Adriatic sea that includes $24,3 \%$ of the total surface of the country. Bosnia and Herzegovina is rich in salt and fresh water resources. There are listed 262 rivers on its territory. Surface waters of FB\&H are, according to the global standards, the waters of high quality. Bosnia and Herzegovina is rich in underground waters. Thermal and mineral waters are one of its most important natural resources. Coast of $\mathrm{B} \& \mathrm{H}$ is south from the delta of Neretva river, its total length is $22 \mathrm{~km}$. Bosnia and Herzegovina has the access to the sea which ahs the surface of $8 \mathrm{~km}^{2}$.
Waters of Bosnia and Herzegovina are unpoluted and in the future they could becoe the initiator of its economic development. Insufficient spatial and temporal distribution of water flow requires the construction of the plant for managing the waters of significat size and complexity, in order to provide rational exploitation of waters, protection of quality and quantity of waters and protection against harmful effects of the water.

Federal law on waters that is under jurisdiction of the Federal Ministry of Agriculture, Waterpower Engineering and Forestry and Federal Ministry of Environment and Tourism has appropriately related competences by this Law, regulates the manner of water management within the territory of Federation of Bosnia \& Herzegovina (water protection, water usage, protection against harmful effect of waters and regulation of waterflow and other waters), water resources, public water resources, water objects, legal entities and other institutions competent for particular issues of water management and other issues related to the waters of FB\&H. The purpose of this law is to reduce the water polution, achieve good state of waters and prevent waters degradation; achievement of sustainable water usage; ensuring a just access to waters; achievement of social and economic development; ecosystem protection; reduction of risk against floods and other negative water impacts; ensuring the participation of the public in making decisions that refer to waters; prevention and solving of the conflicts related to the protection and water usage; meeting the

\footnotetext{
*Corresponding author: amnatravnik@gmail.com
} 
obligations from international contracts that are obligatory for Bosnia and Herzegovina.

The most important characteristic of water is its quality. In the world there is a defined set of indicators of water quality, which are incorporated in the so-called Water Quality Index (WQI). In table 1 is given Water Quality Index (WQI) and status of water quality by C. Chaterjee and M. Razuddin [1].

Table 1. Water quality index (wqi) and status of water quality by c. Chaterjee and m. Razuddin [1]

\begin{tabular}{cc}
\hline $\begin{array}{c}\text { Water Quality Index } \\
\text { (WQI) }\end{array}$ & $\begin{array}{c}\text { Water Quality Status } \\
\text { or } \\
\text { Category }\end{array}$ \\
\hline $\mathbf{0 - 2 5}$ & $\begin{array}{c}\text { Excellent Water } \\
\text { Quality }\end{array}$ \\
& Good Water Quality \\
$\mathbf{2 6 - 5 0}$ & Poor Water Quality \\
$\mathbf{7 6 - 1 0 0}$ & Very Poor Water \\
& Quality \\
$\mathbf{7 1 0 0}$ & Unfit for drinking \\
\hline
\end{tabular}

Analysis of WQI index as an indicator for evaluation and classification of different water types and in different world territories is presented in the following papers: for Lagos (Nigeria) by T. A. Adesalu and D. I. Nwankwo [2], for Douro River by A. A. Bordalo, R. Teixeira and W. J. Wiebe [3], for Warri River (Nigeria) by A. B. M. Egborge and J. Benka-Coker [4], for Tuticorin coastal city (south India) by S. Selvam, G. Manimaran, P. Sivasubramanian, N. Balasubramanian and T. Seshunarayana [5], for five river basins in Europe by C. P. Von der Ohe, A. Prüß, R. B. Schäfer, M. Liess, E. De Deckere and W. Brack [6].

Water quality index (WQI) as management tool is given by N. C. Ferreira, C. Bonetti and W. Q. Seiffert [7] and as classification tool is given by H. Boyacioglu [8] and by P. R. Kannel, S. Lee, Y.-S. Lee, S. R. Kanel and S. P. Khan [9].

WQI for coastal water is given by A. K. Gupta, S. K. Gupta and R. S. Patil [10] and for evaluating surface water quality by F. W. Kaurish and T. Younos [11].

Prediction of WQI by regression analysis (RA) and artificial neural networks (ANN) is given by E. R. Rene and M. B. Saidutta [12].

\section{Data sources and methods}

Data on values of delivered amounts of water according to the springs in FB\&H (in thousands $\mathrm{m}^{3}$ ), are taken from Statistic Yearbooks of the Federation of Bosnia \& Herzegovina (FB\&H) Bureau of Statistics, for the period 2001-2015, Statistical yearbook of Federation of Bosnia \& Herzegovina for 2006 [13], Statistical yearbook of Federation of Bosnia \& Herzegovina for 2009 [14], Statistical yearbook of Federation of Bosnia \& Herzegovina for 2012 [15], Statistical yearbook of Federation of Bosnia \& Herzegovina for 2016 [16], with a certain calculations from the part of the authors. $u$

For the trend analysis, we used the following parameters: annual growth rate (AGR) and cumulative growth index (CGI), described in the papers P. Dašić [17] and R. Tošović, P. Dašić and I. Ristović [18].

For the calculation of statistical descriptions parameter we used software system MS-Excel.

For the graphical presentation of data we used standard statistical analysis methods and software system MS-Excel which is described in the book G. Briand [19], G. Harvey [20], J. Schmuller [21] and W. Winston [22].

\section{Results and Discussion}

Values of the supplied amounts of waters according to the springs in FB\&H (in thousands $\mathrm{m}^{3}$ ), according to the data taken frojm Statistical Yearbooks of the Federation of Bosnia \& Herzegovina (FB\&H) Bureau of Statistics, for the period 2001-2015, Statistical yearbook of Federation of Bosnia \& Herzegovina for 2006 [13], Statistical yearbook of Federation of Bosnia \& Herzegovina for 2009 [14], Statistical yearbook of Federation of Bosnia \& Herzegovina for 2012 [15], Statistical yearbook of Federation of Bosnia \& Herzegovina for 2016 [16], are given in Table 2.

Table 2. Supplied amounts of water according to the springs in FB\&H, for period from 2001-2015 (in thousands $\mathrm{m}^{3}$ )

\begin{tabular}{|cccc|}
\hline Year & TVWPWSS & VWTWSS & Total \\
\hline $\mathbf{2 0 0 1}$ & 219255 & 4074 & 223329 \\
\hline $\mathbf{2 0 0 2}$ & 218292 & 5888 & 224180 \\
\hline $\mathbf{2 0 0 3}$ & 221554 & 7843 & 229397 \\
\hline $\mathbf{2 0 0 4}$ & 229168 & 7936 & 237104 \\
\hline $\mathbf{2 0 0 5}$ & 229573 & 7907 & 237480 \\
\hline $\mathbf{2 0 0 6}$ & 220860 & 7271 & 228131 \\
\hline $\mathbf{2 0 0 7}$ & 217123 & 6437 & 223560 \\
\hline $\mathbf{2 0 0 8}$ & 223156 & 6789 & 229945 \\
\hline $\mathbf{2 0 0 9}$ & 218021 & 7016 & 225037 \\
\hline $\mathbf{2 0 1 0}$ & 219313 & 6570 & 225883 \\
\hline $\mathbf{2 0 1 1}$ & 220814 & 6783 & 227597 \\
\hline $\mathbf{2 0 1 2}$ & 219926 & 6438 & 226364 \\
\hline $\mathbf{2 0 1 3}$ & 219401 & 6971 & 226372 \\
\hline $\mathbf{2 0 1 4}$ & 209668 & 6952 & 216620 \\
\hline $\mathbf{2 0 1 5}$ & 216481 & 7486 & 223967 \\
\hline
\end{tabular}

Note:

TVWPWSS - Total volume of water from the public water supply system,

VWTWSS - Volume of water taken from other water supply systems.

Fig.s 1-3 show a graphical presentation of the trend of supplied amounts of water in FB\&H according to the springs, for the period 2001-2015 (in thousands $\mathrm{m}^{3}$ ) as well as their annual growth rate (AGR) in (\%) for:

1) TVWPWSS (total volume of water from the public water supply system) (Fig. 1);

2) VWTWSS (volume of water taken from other water supply systems) (Fig. 2);

3) Total (Fig. 3).

Value of supplied amounts of water from TVWPWSS (total volume of water from the public water supply system) in FB\&H for period from 2001-2015 (in thousands $\mathrm{m}^{3}$ ) is reduced by $2774 \cdot 10^{3}\left(\mathrm{~m}^{3}\right.$ ) water (from $219255 \cdot 10^{3}\left(\mathrm{~m}^{3}\right)$ water in 2001 to $216481 \cdot 10^{3}\left(\mathrm{~m}^{3}\right)$ water in 2015), with cumulative growth index (CGI) of $98,73 \%$

*Corresponding author: amnatravnik@gmail.com 
in relation to the year 2001., and it also had a continuous trend of supplied amounts of water from TVWPWSS in FB\&H (Fig. 1). Mean value of delivered amounts of water from TVWPWSS in FB\&H for period from 20012015 (in thousands $\mathrm{m}^{3}$ ) is $220174 \cdot 10^{3}\left(\mathrm{~m}^{3}\right)$ of water.

The highest annual growth of supplied amounts of water from TVWPWSS in FB\&H was in 2004 by

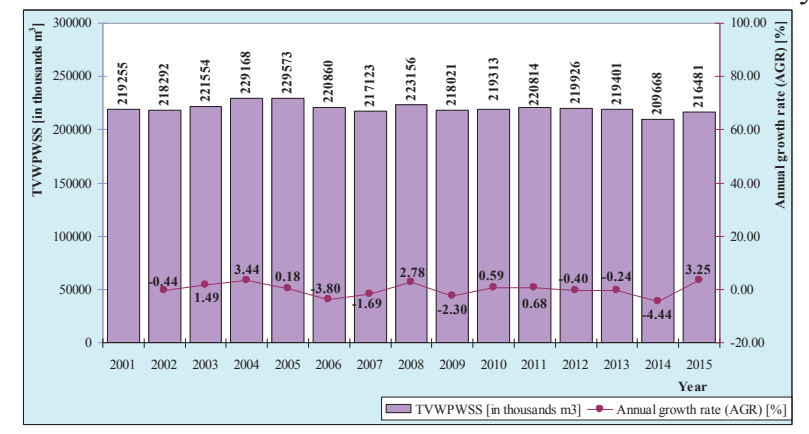

Fig. 1. Graphical presentation of supplied amounts of water from TVWPWSS in FB\&H and their annual growth rate (AGR) in (\%).

Value of the supplied amounts of water from VWTWSS (volume of water taken from other water supply systems) in FB\&H for period from 2001-2015 (in thousands $\mathrm{m}^{3}$ ) was increased by $3412 \cdot 10^{3}\left(\mathrm{~m}^{3}\right)$ water (from $4074 \cdot 10^{3}\left(\mathrm{~m}^{3}\right)$ water in 2001 to $7486 \cdot 10^{3}\left(\mathrm{~m}^{3}\right)$ water in 2015), with cumulative growth index (CGI) by $183,75 \%$ in relation to 2001 ., and it mostly had the trend of growth wavering of the supplied amounts of water from VWTWSS in FB\&H (Fig. 2).

The highest annual growth of supplied water amount from VWTWSS in FB\&H was in 2002 by $1814 \cdot 10^{3}\left(\mathrm{~m}^{3}\right)$ water or by $44,53 \%$, and then in 2003 by $1955 \cdot 10^{3}\left(\mathrm{~m}^{3}\right)$ water or by $33,20 \%$ etc. (Fig. 2).

The highest annual reduction of supplied water amounts from VWTWSS in FB\&H was in 2007 by $636 \cdot 10^{3}\left(\mathrm{~m}^{3}\right)$ water or by $8,04 \%$, and then in 2006 by $834 \cdot 10^{3}\left(\mathrm{~m}^{3}\right)$ water or by $11,47 \%$ etc. (Fig. 2 ).

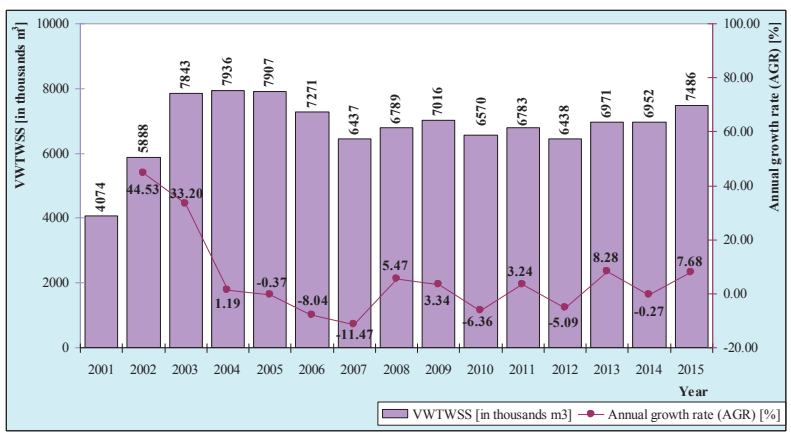

Fig. 2. Grpahical presentation of supplied amounts of water from VWTWSS in FB\&H and their annual growth rate (AGR) in (\%)
$7614 \cdot 10^{3}\left(\mathrm{~m}^{3}\right)$ water or by $3,44 \%$, and then in 2015 for $6813 \cdot 10^{3}\left(\mathrm{~m}^{3}\right)$ water or by $3,25 \%$ etc. (Fig. 1 ).

The highest annual reduction of delivered amounts of water from TVWPWSS in FB\&H was in 2014 by $9733 \cdot 10^{3}\left(\mathrm{~m}^{3}\right)$ water or by $4,44 \%$, and then in 2006 by $8713 \cdot 10^{3}\left(\mathrm{~m}^{3}\right)$ water or by $3,80 \%$ etc. (Fig. 1).

Value of the total supplied amount of water in FB\&H for period from 2001-2015 (in thousands $\mathrm{m}^{3}$ ) was increased by $638 \cdot 10^{3}\left(\mathrm{~m}^{3}\right)$ of water (from $223329 \cdot 10^{3}$ $\left(\mathrm{m}^{3}\right)$ water in 2001 to $223967 \cdot 10^{3}\left(\mathrm{~m}^{3}\right)$ water in 2015$)$, with cumulative growth index (CGI) of 100,29\% in relation to 2001, and it had a continuous trend of total supplied waters in FB\&H (Fig. 3). Mean value of total supplied water amount in FB\&H for the period 20012015 (in thousands $\mathrm{m}^{3}$ ) is $226998 \cdot 10^{3}\left(\mathrm{~m}^{3}\right)$ water.

The highest annual growth of total supplied water amounts in FB\&H was in 2015 by $7347 \cdot 10^{3}\left(\mathrm{~m}^{3}\right)$ water or by $3,39 \%$, and then in 2004 by $7707 \cdot 10^{3}\left(\mathrm{~m}^{3}\right)$ water or by $3,36 \%$ etc. (Fig. 3 ).

The highest annual reduction of total supplied water amount in FB\&H was in 2014 by $9752 \cdot 10^{3}\left(\mathrm{~m}^{3}\right)$ water or by $4,31 \%$, and then in 2006 by $9349 \cdot 10^{3}\left(\mathrm{~m}^{3}\right)$ water or by $3,94 \%$ etc. (Fig. 3).

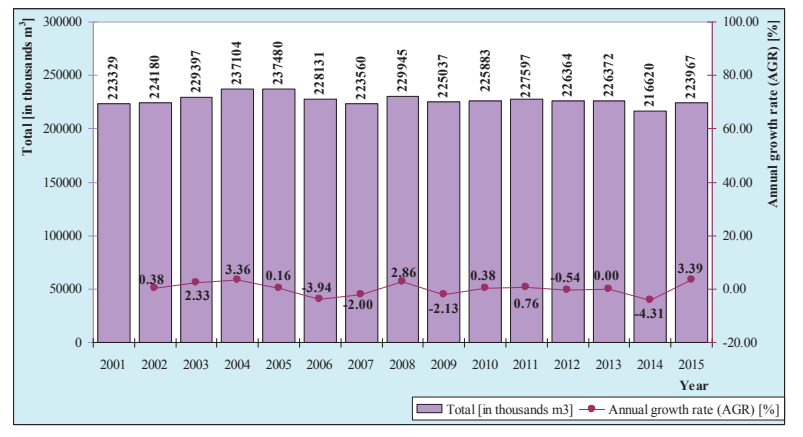

Fig. 3. Graphical presentation of total supplied water amounts in $\mathrm{FB} \& \mathrm{H}$ and their annual growth rate (AGR) in (\%)

Fig. 4 presents a graphical presentation of the structure and share in percents of the springs of supplied water amounts in FB\&H by 2015 (in thousands $\mathrm{m}^{3}$ ).

From the Fig. 9, we can observe that the highest share in percents of the spring of supplied water in FB\&H for 2015 (in thousands $\mathrm{m}^{3}$ ) have the underground waters $(46,72 \%)$, and then springs $(39,29 \%)$ etc. Other water sources of the supplied water amount in FB\&H for 2015 (in thousands $\mathrm{m}^{3}$ ) have only $13,99 \%$ water, and underground waters and springs have 86,01 \%.

*Corresponding author: amnatravnik@gmail.com 


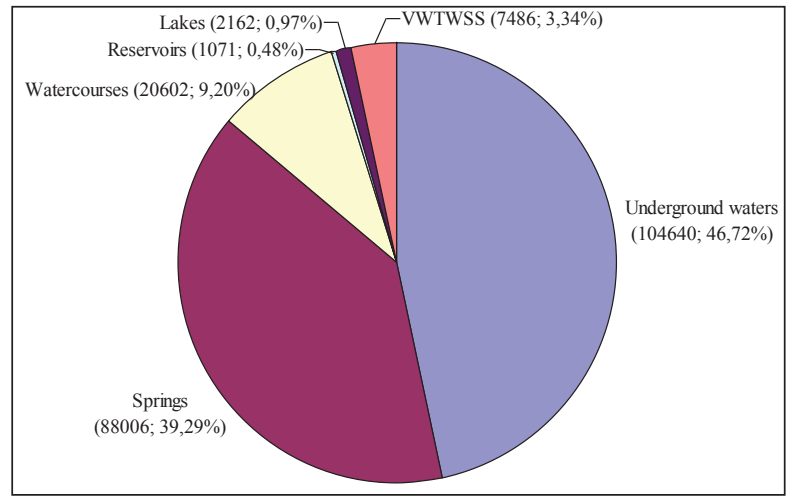

Fig. 4. Graphical presentation of the structure and share in percents of the sources of supplied water amount in FB\&H for 2015 (in thousands $\mathrm{m}^{3}$ )

Statistical descriptions parameter of delivered quantity of water by sources in the FB\&H is given in table 3 .

Table 3. Statistical descriptions parameter of delivered QUANTITY OF WATER BY SOURCES IN THE FB\&H

\begin{tabular}{|c|c|c|c|c|}
\hline \multirow{2}{*}{ Minimum } & \multirow{2}{*}{$\begin{array}{l}\frac{5}{5} \\
\text { Min }\end{array}$} & \multirow{2}{*}{$\sum_{\substack{\infty \\
\infty}}^{\infty}$} & & స्ञ \\
\hline & & & 4074 & 216620 \\
\hline Maximum & Max & $0.22 \mathrm{mil}$ & 7936 & 237480 \\
\hline Range & $\mathrm{Rx}$ & $0.02 \mathrm{mil}$ & 3862 & 20860 \\
\hline Total & Sum & $3.3 \mathrm{mil}$ & 102361 & 3404966 \\
\hline $\begin{array}{l}\text { Arithmenti } \\
\text { c mean }\end{array}$ & Aver & $0.22 \mathrm{mil}$ & 6824.067 & 226997.733 \\
\hline $\begin{array}{l}\text { Geometric } \\
\text { mean }\end{array}$ & GM & $0.22 \mathrm{mil}$ & 6748.025 & 226941.704 \\
\hline $\begin{array}{l}\text { Harmonic } \\
\text { mean }\end{array}$ & $\mathrm{HM}$ & $0.22 \mathrm{mil}$ & 6655.340 & 226886.032 \\
\hline Median & Med & $0.22 \mathrm{mil}$ & 6952 & 226364 \\
\hline $\begin{array}{l}\text { Std. } \\
\text { deviation }\end{array}$ & SD & $0.004 \mathrm{mil}$ & 962.344 & 5237.782 \\
\hline Variance & Var & $23.18 \mathrm{mil}$ & 926106.210 & $\begin{array}{c}27434357.9 \\
24\end{array}$ \\
\hline $\begin{array}{l}\text { Coef. of } \\
\text { variation }\end{array}$ & $\mathrm{CV}$ & 2.187 & 14.102 & 2.307 \\
\hline Skewness & Sk & 0.244 & -1.633 & 0.549 \\
\hline Kurtosis & $\mathrm{Ku}$ & 1.732 & 4.204 & 1.297 \\
\hline
\end{tabular}

\section{Conclusion}

Continuous trend of supplied water amounts in FB\&H for the period 2001-2015 had the water from TVWPWSS (total volume of water from the public water supplysystem) (Fig. 1) with cumulative growth index (CGI) by $98,73 \%$ in relation to 2001 . and mean value of $220174 \cdot 10^{3}\left(\mathrm{~m}^{3}\right)$ water and total supplied water amount (Fig. 3) with the cumulative growth index (CGI) by $100,29 \%$ in relation to 2001 and mean value of $226998 \cdot 10^{3}\left(\mathrm{~m}^{3}\right)$ water.

Trend of a great growth wavering of the value of delivered amounts of water in FB\&H for the period 2001-2015 had the waters from VWTWSS (volume of water taken from other water supply systems) (Fig. 2)
Fig. 5 graphically presents arithmentic (Aver), geometric (GM) and harmonic mean (HM) and median (Med) for delivered quantity of water by sources in the FB\&H.

Minimum value of delivered amounts of water from TVWPWSS in FB\&H for period from 2001-2015 was 209668 (in thousands $\mathrm{m}^{3}$ ) in 2014, and maximum 229573 (in thousands $\mathrm{m}^{3}$ ) in 2005 .

Minimum value of supplied water amounts from VWTWSS in FB\&H for period from 2001-2015 was 4074 (in thousands $\mathrm{m}^{3}$ ) in 2001, and maximum 7936 (in thousands $\mathrm{m}^{3}$ ) in 2004 .

Minimum value of the total supplied water amounts in FB\&H for period from 2001-2015 was 216620 (in thousands $\mathrm{m}^{3}$ ) in 2014, and maximum 237480 (in thousands $\mathrm{m}^{3}$ ) 2005 .

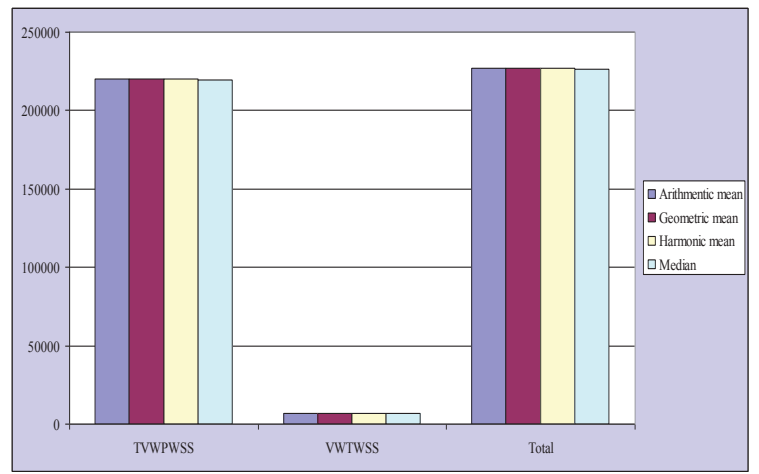

Fig. 5. Graphical representation arithmentic (Aver),

geometric (GM) and harmonic mean (HM) and median (Med)

with cumulative growth index (CGI) by $183,75 \%$ in relation to 2001 .

Based on the structure and share in percents of the sources of supplied water amounts in FB\&H for 2015 (in thousands $\mathrm{m}^{3}$ ) (Fig. 4) have the waters from underground waters $(46,72 \%)$, and then the waters from springs $(39,29 \%)$. Waters from underground waters $(46,72 \%)$ and waters from springs have a percentage share of $86,01 \%$ in supplied water amounts in FB\&H for 2015 (in thousands $\mathrm{m}^{3}$ ) while the other sources have a percentage share of only $13,99 \%$.

The arithmetic mean value of the delivered amount of water in FB\&H for the period 2001-2015 (in thousands of $\left.\mathrm{m}^{3}\right)$ is $226998 \times 10^{3}\left(\mathrm{~m}^{3}\right)$ of water, geometric mean is $226942 \times 10^{3}\left(\mathrm{~m}^{3}\right)$ and harmonic mean is $226886 \times 10^{3}$ $\left(\mathrm{m}^{3}\right)$. Sum of total delivered amount of water in FB\&H for period 2001-2015 (in thousands of $\mathrm{m}^{3}$ ) was $3404966 \times 10^{3}\left(\mathrm{~m}^{3}\right)$ of water. The value of the total delivered amount of water in FB\&H for the period 20012015 (in thousands of $\mathrm{m}^{3}$ ) had a constant trend of the total delivered amount of water in FB\&H, and has increased by $638 \times 10^{3}\left(\mathrm{~m}^{3}\right)$ of water (from $223329 \times 10^{3}$ $\left(\mathrm{m}^{3}\right)$ of water in 2001 to $223967 \times 10^{3}\left(\mathrm{~m}^{3}\right)$ of water in 2015), with a cumulative growth index (CGI) of $100.29 \%$ compared to 2001. Largest annual growth of

*Corresponding author: amnatravnik@gmail.com 
total delivered amount of water in FB\&H was in 2015 for $7347 \times 10^{3}\left(\mathrm{~m}^{3}\right)$ of water or for $3,39 \%$ etc. Highest annual decrease of total delivered amount of water in FB\&H was in 2014 for $9752 \times 10^{3}\left(\mathrm{~m}^{3}\right)$ of water or for $4,31 \%$ etc.

\section{References}

[1] C. Chaterjee, and M. Razuddin, "Determination of Water Quality Index (W.Q.I.) of a degraded river in Asanil Industrial area, Ranigunj, Burdwan, West Bengal Nature," Environment and Pollution Technology, vol. 1, no. 2, pp. 181-189, 2002.

[2] Adesalu, T.A. and Nwankwo, D.I.: "Effect of water quality indices on phytoplankton of a sluggish tidal creek in Lagos, Nigeria," Pakistan Journal of Biological Sciences, vol. 11, no. 6, pp. 836-844, 2008. doi: 10.3923/pjbs.2008.836.844.

[3] A. A. Bordalo, R. Teixeira, and W. J. Wiebe, "A water quality index applied to an international shared river basin: The case of the Douro River," Environmental Management, vol. 38, no. 6, pp. 910-920, 2006. doi: 10.1007/s00267-004-0037-6.

[4] A. B. M. Egborge, and J. Benka-Coker, "Water quality index: Application in the Warri River, Nigeria," Environmental Pollution. Series B, Chemical and Physical, vol. 12, no. 1, pp. 2740, 1986. doi: 10.1016/0143-148X(86)90004-2.

[5] S. Selvam, G. Manimaran, P. Sivasubramanian, N. Balasubramanian, and T. Seshunarayana, "GIS-based evaluation of Water Quality Index of groundwater resources around Tuticorin coastal city, south India," Environmental Earth Sciences, vol. 71, no. 6, pp. 2847-2867, 2014. doi: 10.1007/s12665-013-2662-y.

[6] C. P. Von der Ohe, A. Prüß, R. B. Schäfer, M. Liess, E. De Deckere, and W. Brack, "Water quality indices across Europe - A comparison of the good ecological status of five river basins," Journal of Environmental Monitoring, vol. 9, no. 9, pp. 970-978, 2007. doi: 10.1039/b704699p.

[7] N. C. Ferreira, C. Bonetti, and W. Q. Seiffert, "Hydrological and Water Quality Indices as management tools in marine shrimp culture," Aquaculture, vol. 318, no. 3-4, pp. 425-433, 2011. doi: 10.1016/j.aquaculture.2011.05.045.

[8] H. Boyacioglu, "Utilization of the water quality index method as a classification tool," Environmental Monitoring and Assessment, vol. 167 , no. $1-4$, pp. 115-124, 2010. doi: 10.1007/s10661-0091035-1.

[9] P. R. Kannel, S. Lee, Y.-S. Lee, S. R. Kanel, and S. P. Khan, "Application of water quality indices and dissolved oxygen as indicators for river water classification and urban impact. assessment," Environmental Monitoring and Assessment, vol. 132, no. 1-3, pp. 93-110, 2007. doi: 10.1007/s10661-006-9505-1.

[10] A. K. Gupta, S. K. Gupta, and R. S. Patil, "A comparison of water quality indices for coastal water," Journal of Environmental Science and Health - Part A Toxic/Hazardous Substances and Environmental Engineering, vol. 38, no. 11, pp. 2711-2725, 2003. doi: 10.1081/ESE-120024458.

[11] F. W. Kaurish, and T. Younos, "Developing a standardized water quality index for evaluating surface water quality," Journal of the American Water Resources Association, vol. 43, no 2, pp. 533545, 2007. doi: 10.1111/j.1752-1688.2007.00042.x.

[12] E. R. Rene, and M. B. Saidutta, "Prediction of water quality indices by regression analysis and artificial neural networks," International Journal of Environmental Research, vol. 2, no. 2, pp. 183-188, 2008.

[13] Statistical yearbook of Federation of Bosnia \& Herzegovina for 2006. Sarajevo, Bosnia \& Herzegovina: Institute for Statistics of the FB\&H, 2006, pp. 465.

[14] Statistical yearbook of Federation of Bosnia \& Herzegovina for 2009. Sarajevo, Bosnia \& Herzegovina: Institute for Statistics of the FB\&H, 2009, pp. 513.

[15] Statistical yearbook of Federation of Bosnia \& Herzegovina for 2012. Sarajevo, Bosnia \& Herzegovina: Institute for Statistics of the FB\&H, 2012, pp. 532.

[16] Statistical yearbook of Federation of Bosnia \& Herzegovina for 2016. Sarajevo, Bosnia \& Herzegovina: Institute for Statistics of the FB\&H, 2016, pp. 506.

[17] P. Dašić, "Application of polynomial regression models for approximation of time series," Journal of Economic and Management Based on New Technologies, vol. 1, no. 2, pp. 81160, 2012.

[18] R. Tošović, P. Dašić, and I. Ristović, "Sustainable use of metallic mineral resources of Serbia from an environmental perspective," Environmental Engineering and Management Journal, vol. 15, no. 9, pp. 2075-2084, 2016.

[19] G. Briand, Using Excel for principles of econometrics. (4th Edition), Hoboken, New Jersey: John Wiley \& Sons Inc., 2011, pp. 484.

[20] G. Harvey, Excel 2016 for dummies. Hoboken, New Jersey: John Wiley \& Sons Inc., 2016, 432 pp.

[21] J. Schmuller, Statistical analysis with Excel for dummies. (4th Revised Edition). Hoboken, New Jersey: John Wiley \& Sons Inc., 2016, $552 \mathrm{pp}$.

[22] W. Winston, Microsoft Excel data analysis and business modeling. (5th Edition). Redmond, Washington: Microsoft Press, 2016, pp. 864. 